\title{
INTERACTION OF RED GRAPE EXTRACT AND NICOTINE ON AGING
}

\author{
M.Subahan $^{1}$, K.Khalindar Basha ${ }^{2}$, *K.Chennaiah ${ }^{3}$, S. Kishore ${ }^{4}$, M.Vani ${ }^{5}$, P.S.Poornima ${ }^{6}$, \\ M.Venkatramudu ${ }^{7}$, P. Nagaraju ${ }^{8}$ and K.Sathyavelu Reddy
}

$\mathbf{1 , 2 , 3 , 4 , 9}$ Department of Zoology, Sri Venkateswara University, Tirupati, Andhra Pradesh, India-517502.
${ }^{\mathbf{5 , 6}}$ Department of Zoology, Sri Venkateswara Arts College, Tirupati, Andhra Pradesh, India-517502
${ }^{7}$ Department of Zoology, Sri Krishna Devaraya University, Anantapuramu.
${ }^{8}$ Department of Environmental Science, S.V. University, Tirupati, Andhra Pradesh, India-517502.

\section{Abstract}

Cigarette smoking (Nicotiana Tabacum. L) is also a risk factor for respiratory tract and othe. infections, osteoporosis, reproductive disorders, adverse postoperative events and delayed wound healing, duodenal and gastric ulcers and diabetes. Consumption of Red grape flavonoids has been shown to confer antioxidant protection. In the present study antioxidant has been assessed in nicotine administered rats to examine the effects of nicotine on the antioxidant defense systems in heart of male albino rat. Age matched rats were be divided into 4 groups of six in each group and treated as follows: Group I. Normal Control (NC) (Control rats received 0.9\% saline). Group II. Nicotine treated (Nt) (at a dose of $0.6 \mathrm{mg} / \mathrm{kg}$ body weight by subcutaneous injection for a period of 2 months). Group III. Red grape extract treated (RGEt). (Red grape extract at a doses of $25 \mathrm{mg} / \mathrm{kg}$ body weight via orogastric tube for a period of 2 months). Group IV. Nicotine + red grape extract treated (Nt+RGEt) (The forth group of rats were received the nicotine + red grape extract as followed by the second and third group). The enzymes such as Superoxide dismutase(SOD), Catalase(CAT), Glutathione (GSH) and Glutathione peroxidase (GSH-Px) were significantly decreased in nicotine treated rats in heart tissue and increase was observed in the combination treatment $(\mathrm{Nt}+\mathrm{RGEt})$, This study suggests that red grape extract treatment may be beneficial for nicotine intoxications.

Key Words: Nicotine, Red Grape Extract, Superoxide dismutase (SOD), Catalase (CAT), Glutathione (GSH), Glutathione peroxidase (GSH-Px), Heart tissue and Male albino rats.

\section{*Corresponding author: \\ ${ }^{3}$ Dr.K.Chennaiah,}

Asst. Professor,

Dept.of Zoology,

S.V.University, Tirupati

A.P., India-517502.

\section{INTRODUCTION:}

Grape (Vitis vinifera L.) is one of the most commonly consumed fruit growing worldwide. The total amount about $80 \%$ is used in wine making (Maier et al., 2009) and the grape byproduct consists $20 \%$ of weight from winery process (Lafka et al., 2007). In Thailand, grape is usually processed into various products such as wine, juice and raisins. Black queen is one of the grape varieties that is normally processed into wine and juice and the large quantity of byproducts from both processes such 
as pomace (grape pulp, peels and seeds) were obtained and there has been several studies showing that these kind of by products could be a good source of antioxidants such as polyphenols and flavonoids. Wine is considered to be a high bioactive polyphenol content source. Many studies have revealed the key role played by phenolic compounds from grapes and wine on human health; cardiovascular diseases being the pathologies that have received much attention (Pozo-Bayón et al., 2012, Arranz et al., 2012). Wine is a widely consumed beverage in the world, with thousands of years of tradition. The phenolic compounds in grape berries are responsible for some of the major organoleptic properties of wine, such as color, astringency, bitterness, and aroma (Minussi et al., 2003; Pérez-Magariño and González-Sanjosé, 2006). During the red winemaking process, phenolic compounds from the skins of red grapes transfer to the must during the fermentation and any maceration steps (Salas et al., 2003). Based on their carbon skeleton, phenolic compounds are divided into two groups: flavonoid (anthocyanins, flavan-3-ols, flavonols) and non-flavonoid compounds (hydroxybenzoic and hydroxycinnamic acids, stilbenes). Different types of phenolic compounds endow grape varieties and wines with specific quality characteristics.

Nicotine are highly addictive (Grana et al., 2014; Holbrook and Bradley, 2016). An average cigarette yields about $2 \mathrm{mg}$ of absorbed nicotine, and in lesser doses of that order, the substance acts as a stimulant in mammals, while high amounts (50-100 mg) can be harmful (Mayer, 2014). This stimulant effect is a contributing factor to the addictive properties of tobacco smoking. Nicotine's addictive nature includes psychoactive effects, drug-reinforced behavior, compulsive use, relapse after abstinence, physical dependence and tolerance (Caponnetto et al., 2012). Nicotine is a natural ingredient acting as a botanical insecticide in tobacco leaves. It is the principal tobacco alkaloid, occurring to the extent of about $1.5 \%$ by weight in commercial cigarette tobacco and comprising about $95 \%$ of the total alkaloid content. Oral snuff and pipe tobacco contain concentrations of nicotine similar to cigarette tobacco, whereas cigar and chewing tobacco have only about half the nicotine concentration of cigarette tobacco. An average tobacco rod contains 10-14 mg of nicotine (Kozlowski et al., 1998), and on average about $1-1.5 \mathrm{mg}$ of nicotine is absorbed systemically during smoking (Benowitz and Jacob 1984). Nicotine in tobacco is largely the levorotary $(S)$-isomer; only $0.1-0.6 \%$ of total nicotine content is $(R)$-nicotine (Armstrong et al., 1998). Chemical reagents and pharmaceutical formulations of $(S)$-nicotine have a similar content of $(R)$-nicotine $(0.1-1.2 \%)$ as impurity since plantderived nicotine is used for their manufacture.

In most tobacco strains, nor nicotine and anatabine are the most abundant of minor alkaloids, followed by anabasine. This order of abundance is the same in cigarette tobacco and oral snuff, chewing, pipe, and cigar tobacco (Jacob et al., 1999). However, nornicotine levels are highest in cigar tobacco, anatabine levels are lowest in chewing tobacco and oral snuff, and anabasine levels are lowest in chewing tobacco (Jacob et al., 1999). Small amounts of the $N_{-}$-methyl derivatives of anabasine and anatabine are found in tobacco and tobacco smoke. Several of the minor alkaloids are thought to arise by bacterial action or oxidation during tobacco processing rather than by biosynthetic processes in the living plant (Leete, 1983). These include myosmine, $N_{-}$-methylmyosmine, cotinine, nicotyrine, nornicotyrine, nicotine $N_{-}$-oxide, 2, 3_-bipyridyl, and metanicotine. Myosmine is found not only in tobacco but also in a variety of foods including nuts, cereals, milk, and potatoes (Tyroller et al., 2002). Also, nicotine is found in low levels in vegetables such as potatoes, tomatoes, and eggplants (Siegmund et al., 1999).

Aging, an unwanted, unavoidable and universal biological phenomenon, is caused by time dependent progressive deleterious and irreversible changes occurring in cells, organs and in the total organism (Patel, 1981). Metabolic machinery of the body deteriorates at an increasing rate after the organism reaches its reproductive maturity (Shock, 1979). Aging may be described as a phenomenon which results from the accumulation of changes in informational biomolecules and is responsible for both the diminished bodily functions with advancing age and associated progressive increase in the 
chance of diseases and death (Harman, 1992; Masoro, 1993). Numerous definitions has been given by various scientists for aging.Hence, this study was designed to investigate the effects of red grape extract on nicotine induced oxidative stress in the heart tissue of male albino rat with reference to aging.

\section{METERIALS AND METHODS:}

\section{CARE AND MAINTENANCE OF EXPERIMENTAL ANIMALS}

Pathogen free, wistar strain male albino rats of two age groups ( 3 months and 18 months) 3 months age group considered as 'Young age' and 18 months age group considered as 'Old age' as per the life span of Wistar strain, (Jang et al.,2001) were used in the present study. The usage of animals was approved by the Institutional Animal Ethics Committee (Regd.No. 438/01/a/CPCSEA/dt.17-22001) in its resolution number 9/IAEC/SVU/Zool/dt.4-3-2002. The rats were housed in clean polypropylene cages under hygienic conditions with photoperiod of 12 hours light and 12 hours dark. The rats were fed with standard laboratory chow (Hindustan Lever Ltd, Mumbai) and water ad libitum.

\section{CHEMICALS:}

Nicotine and other fine chemical were obtained from Sigma chemical company, St. Louis, USA. All other chemicals and reagent used were of analytical grade.

\section{PREPARATION OF RED GRRAPE EXTRACTION:}

Red Grapes, as large clusters with red berries, were brought from a local supermarket in Banglore and identified as Vitis vinifera L.(Family Vitaceae) The grape were crushed (whole fruit) for juice and dried in shade, powdered and extract by maceration with $70 \%(\mathrm{~W} / \mathrm{V})$ alcoholic for $72 \mathrm{~h}$ in ambient temperature. The red grape extract was filtered and then solvent evapored to dryness under reduced pressure in a rotary evaporator. The residual red grape extract was used for this study.

\section{EXPERIMENTAL DESIGN:}

Age matched rats were divided into 4 groups of six in each groups. i) Narmal Control (NC) (Six rats were put on a six-channel, the rats were treated with normal saline $(0.9 \%)$ orally via orogastic tube for a period of 2 months.). ii) Nicotine treatment (Nt) (Rats were received the nicotine at a dose of $0.6 \mathrm{mg} / \mathrm{kg}$ body weight $(0.5 \mathrm{ml})$ by subcutaneous injection for a period of 2 months). iii) Red Grape extracts treatment (RGEt) (Rats were received red grape extract $25 \mathrm{mg} / \mathrm{kg}$ body weight via orogastric tube for a period of 2 months), and iv) Nicotine + Red Grape extract treatment (Nt+RGEt), (Rats were received the nicotine at a dose of $0.6 \mathrm{mg} / \mathrm{kg}$ body weight $(0.5 \mathrm{ml})$ by subcutaneous injection and red grape extract $25 \mathrm{mg} / \mathrm{kg}$ body weight via orogastric tube for a period of 2 months). The animals were sacrificed after $24 \mathrm{hrs}$ after the last treatment session by cervical dislocation and the heart tissue, were isolated at $-4^{0}$, washed with ice-cold saline, immediately immersed in liquid nitrogen and stored at $80^{\circ}$ for biochemical analysis and enzymatic assays. Before assay, the tissues were thawed, sliced and homogenized under ice-cold conditions. Selected parameters were estimated by employing standard methods.

\section{BIOCHEMICAL ANALYSIS:}

\section{Superoxide Dismutase (SOD - EC: 1.15.1.6):}

Superoxide dismutase activity was determined according to the method of Misra and Fridovich, (1972) at room temperature. The heart tissue was homogenized in ice cold $50 \mathrm{mM}$ phosphate buffer ( $\mathrm{pH} 7.0$ ) containing $0.1 \mathrm{mM}$ EDTA to give $5 \%$ homogenate (W/V). The homogenates were centrifuged at $10,000 \mathrm{rpm}$ for $10 \mathrm{~min}$ at $40 \mathrm{C}$ in cold centrifuge. The supernatant 
was separated and used for enzyme assay. $100 \mu \mathrm{l}$ of tissue extract was added to $880 \mu \mathrm{l}(0.05 \mathrm{M}, \mathrm{pH}$ 10.2, containing $0.1 \mathrm{mM}$ EDTA) carbonate buffer; and $20 \mu \mathrm{l}$ of $30 \mathrm{mM}$ epinephrine (in $0.05 \%$ acetic acid) was added to the mixture and measured the optical density values at $480 \mathrm{~nm}$ for 4 min on a Hitachi U-2000 Spectrophotometer. Activity expressed as the amount of enzyme that inhibits the oxidation of epinephrine by $50 \%$, which is equal to 1 unit.

\section{Catalase (CAT - EC: 1.11.1.6):}

Catalase activity was measured by a slightly modified version of Aebi, (1984) at room temperature. The heart tissue was homogenized in ice cold $50 \mathrm{mM}$ phosphate buffer ( $\mathrm{pH} 7.0$ ) containing $0.1 \mathrm{mM}$ EDTA to give $5 \%$ homogenate $(\mathrm{W} / \mathrm{V})$. The homogenates were centrifuged at $10,000 \mathrm{rpm}$ for $10 \mathrm{~min}$ at $40 \mathrm{C}$ in cold centrifuge. The resulting supernatant was used as enzyme source. $10 \mu \mathrm{l}$ of $100 \% \mathrm{EtOH}$ was added to $100 \mu \mathrm{l}$ of tissue extract and then placed in an ice bath for 30 min. After $30 \mathrm{~min}$ the tubes were kept at room temperature followed by the addition of $10 \mu \mathrm{l}$ of Triton X-100 RS. In a cuvette containing $200 \mu \mathrm{l}$ of phosphate buffer and $50 \mu \mathrm{l}$ of tissue extract was added $250 \mu \mathrm{l}$ of $0.066 \mathrm{M} \mathrm{H} 2 \mathrm{O} 2$ (in phosphate buffer) and decreases in optical density measured at $240 \mathrm{~nm}$ for $60 \mathrm{~s}$ in a UV spectrophotometer. The molar extinction coefficient of $43.6 \mathrm{M} \mathrm{cm}-1$ was used to determine CAT activity. One unit of activity is equal to the moles of $\mathrm{H} 2 \mathrm{O} 2$ degraded / $\mathrm{mg}$ protein / $\min$.

\section{Glutathione (GSH) Content:}

Glutathione content was determined according to the method of Theodorus et.al., (1981). The heart tissue was homogenized in $0.1 \mathrm{M}$ ice cold phosphate buffer $(\mathrm{pH} 7.0)$ containing $0.001 \mathrm{M}$ EDTA and protein is precipitated with $1 \mathrm{ml}$ of $5 \%$ sulfosalicylic acid $(\mathrm{W} / \mathrm{V})$ and the contents were centrifuged at $5000 \mathrm{~g}$ for $15 \mathrm{~min}$ at $40 \mathrm{C}$. The resulting supernatant was used as the enzyme source. The reaction mixture in a total volume of $2.5 \mathrm{ml}$ contained $2.0 \mathrm{ml}$ of $0.1 \mathrm{M}$ potassium phosphate buffer, $0.05 \mathrm{ml}$ of NADPH (4 mg / $\mathrm{ml}$ of $0.5 \%$ NaHCO3), $0.02 \mathrm{ml}$ of DTNB $(1.5 \mathrm{mg} / \mathrm{ml}), 0.02 \mathrm{ml}$ of glutathione reductase $(6$ units/ $\mathrm{ml}$ ) and required amount of tissue source. The reaction was initiating by adding $0.41 \mathrm{ml}$ of enzyme source and change in absorbance was recorded at $425 \mathrm{~nm}$ against the reagent blank. The glutathione content was expressed in nano moles/ gram wet weight of the tissue.

\section{Glutathione Peroxidase (GSH-PX - EC: 1.11.1.9):}

Glutathione peroxidase (GSH-Px) was determined by a modified version of Flohe and Gunzler (1984). At 370C 5\% (W/V) of heart tissue homogenate was prepared in $50 \mathrm{mM}$ phosphate buffer (pH 7.0) containing $0.1 \mathrm{mM}$ EDTA. The homogenates were centrifuged at $10,000 \mathrm{rpm}$ for $10 \mathrm{~min}$ at $40 \mathrm{C}$ in cold centrifuge. The resulting supernatant was used as enzyme source. The reaction mixture consisted of $500 \mu \mathrm{l}$ of phosphate buffer, $100 \mu \mathrm{l}$ of $0.01 \mathrm{M} \mathrm{GSH}$ (reduced form), $100 \mu \mathrm{l}$ of $1.5 \mathrm{mM}$ NADPH and $100 \mu \mathrm{l}$ of GR ( 0.24 units). The $100 \mu \mathrm{l}$ of tissue extract was added to the reaction mixture and incubated at $370 \mathrm{C}$ for $10 \mathrm{~min}$. Then $50 \mu \mathrm{l}$ of $12 \mathrm{mM}$ t-butyl hydroperoxide was added to $450 \mu \mathrm{l}$ of tissue reaction mixture and measured at $340 \mathrm{~nm}$ for $180 \mathrm{~s}$. The molar extinction coefficient of $6.22 \times 103 \mathrm{M} \mathrm{cm}-1$ was used to determine the activity. One unit of activity is equal to the $\mathrm{mM}$ of NADPH oxidized / $\mathrm{mg}$ protein/ $\mathrm{min}$. The enzyme activity was expressed in $\mu$ moles of NADPH oxidized/ $\mathrm{mg}$ protein $/ \mathrm{min}$.

\section{PROTEIN ASSAY:}

Protein content where ever mentioned was estimated by the method of Lowry et al., (1951) using bovine serum albumin as standard.

\section{STATISTICAL ANALYSIS}

Statistical analysis has been carried out using INSTAT software. The data was analyzed for the significance; the results were presented with the P-values. 


\section{RESULTS:}

In the present study the Superoxide dismutase activity was decreased in both (young and old) nicotine treatment rats (young by $-26.91 \%$; old by $-12.58 \%$ ) when compared to control rats. In red grape extract treated rats of both (young and old) an increased was observed when compared to the control rats (young by $14.33 \%$; old by $13.30 \%$ ). In the combination treatment (Nt+RGEt) slightly increased was observed when compared to control rats of both age groups. (Table-1).

Table-1: Changes in Superoxide dismutase (SOD) activity in Heart tissue of male albino rats of young (3 months) and old (18 months) age groups. Values are expressed in units of Superoxide anion reduced/ $\mathrm{mg}$ proteins.

\begin{tabular}{|c|c|c|c|c|c|c|c|c|}
\hline \multirow{2}{*}{$\begin{array}{l}\text { Name } \\
\text { of the } \\
\text { tissue }\end{array}$} & \multicolumn{4}{|c|}{ Young } & \multicolumn{4}{|c|}{ Old } \\
\hline & Control & $\mathrm{Nt}$ & RGEt & $\mathrm{Nt}+\mathrm{RGEt}$ & $\begin{array}{c}\text { Contro } \\
1\end{array}$ & $\mathrm{Nt}$ & RGEt & $\begin{array}{c}\mathrm{Nt}+\mathrm{RGE} \\
\mathrm{t}\end{array}$ \\
\hline Heart & $\begin{array}{l}157.84 \\
\pm 12.37\end{array}$ & $\begin{array}{c}123.53 * * \\
\pm 8.45 \\
(-21.73)\end{array}$ & $\begin{array}{c}183.82 * * \\
\pm 9.09 \\
(+16.45)\end{array}$ & $\begin{array}{r}160.32^{@} \\
\pm 10.90 \\
(+1.57)\end{array}$ & $\begin{array}{l}151.21 \\
\pm 11.73\end{array}$ & $\begin{array}{c}119.12 * * \\
\pm 4.60 \\
(-21.22)\end{array}$ & $\begin{array}{c}154.52 * * \\
\pm 8.78 \\
(+2.18)\end{array}$ & $\begin{array}{c}152.43^{@} \\
\pm 11.73 \\
(+0.80)\end{array}$ \\
\hline
\end{tabular}

All the values are \pm SD of six individual observations.

Values in parentheses denote per cent change over respective control.

** Values are significant at $\mathrm{P}<0.01$

@ Values are non significant

In the present study the Catalase activity was decreased in both (young and old) nicotine treated rats (young by $-31.43 \%$; old by $-22.94 \%$ ) when compared to control rats. In red grape extract treated rats of both (young and old) an increased was observed when compared to the control rats (young by $12.82 \%$; old by $22.58 \%$ ). In the combination treatment (Nt+RGEt) slightly increased was observed when compared to control rats of both age groups (Table-2).

Table-2: Changes in Catalase (CAT) activity in Heart tissue of male albino rats of young (3 months) and old (18 months) age groups. Values are expressed in $\mu$ moles of $\mathrm{H} 2 \mathrm{O} 2$ cleaved $/ \mathrm{mg}$ protein $/ \mathrm{min}$.

\begin{tabular}{|c|c|c|c|c|c|c|c|c|}
\hline \multirow{2}{*}{$\begin{array}{l}\text { Name } \\
\text { of the } \\
\text { tissue }\end{array}$} & \multicolumn{4}{|c|}{ Young } & \multicolumn{4}{|c|}{ Old } \\
\hline & Control & $\mathrm{Nt}$ & RGEt & $\begin{array}{c}\mathrm{Nt}+\mathrm{RGE} \\
\mathrm{t}\end{array}$ & Control & $\mathrm{Nt}$ & RGEt & $\begin{array}{c}\mathrm{Nt}+\mathrm{RGE} \\
\mathrm{t}\end{array}$ \\
\hline Heart & $\begin{array}{l}118.48 \\
\pm 7 . .16\end{array}$ & $\begin{array}{c}85.84 * * \\
\pm 7.33 \\
(-27.54)\end{array}$ & $\begin{array}{c}127.23 * * \\
\pm 5.70 \\
(+7.38)\end{array}$ & $\begin{array}{c}120.20^{@} \\
\pm 6.03 \\
(+2.03)\end{array}$ & $\begin{array}{c}104.60 \\
\pm 9.57\end{array}$ & $\begin{array}{c}83.00 * * \\
\pm 7.25 \\
(-20.65)\end{array}$ & $\begin{array}{c}113.91 * * \\
\pm 5.70 \\
(+8.90)\end{array}$ & $\begin{array}{c}106.28^{@} \\
\pm 7.26 \\
(+1.60)\end{array}$ \\
\hline
\end{tabular}

All the values are \pm SD of six individual observations.

Values in parentheses denote per cent change over respective control.

$* \quad$ Values are significant at $\mathrm{P}<0.05$

** Values are significant at $\mathrm{P}<0.01$

${ }^{\circledR}$ Values are non significant

In the present study the Glutathione content was decreased in both (young and old) nicotine treated rats (young by $-11.00 \%$; old by $-9.84 \%$ ) when compared to control rats. In red grape extract treated rats of both (young and old) an increased was observed when copared to the control rats 
(young by $6.87 \%$; old by $8.17 \%$ ). In the combination treatment (Nt+RGEt) slightly increased was observed when compared to control rats of both age groups (Table-3).

Table-3: Changes in Glutathione (GSH) activity in Heart tissue of male albino rats of young (3 months) and old (18 months) age groups. Values are expressed in $n$ moles of glutathione/ gm/ wet wt of tissue.

\begin{tabular}{|c|c|c|c|c|c|c|c|c|}
\hline \multirow{2}{*}{$\begin{array}{l}\text { Name } \\
\text { of the } \\
\text { tissue }\end{array}$} & \multicolumn{4}{|c|}{ Young } & \multicolumn{4}{|c|}{ Old } \\
\hline & Control & $\mathrm{Nt}$ & RGEt & $\mathrm{Nt}+\mathrm{RGEt}$ & $\begin{array}{c}\text { Contro } \\
1 \\
\end{array}$ & $\mathrm{Nt}$ & RGEt & $\begin{array}{c}\mathrm{Nt}+\mathrm{RGE} \\
\mathrm{t}\end{array}$ \\
\hline Heart & $\begin{array}{c}175.30 \\
\pm 7.87\end{array}$ & $\begin{array}{c}157.15^{*} \\
* \\
\pm 5.95 \\
(-10.35)\end{array}$ & $\begin{array}{c}185.44 * * \\
\pm 5.13 \\
(+5.78)\end{array}$ & $\begin{array}{c}177.10^{@} \\
\pm 7.87 \\
(+1.02)\end{array}$ & $\begin{array}{c}165.54 \\
\pm 3.46\end{array}$ & $\begin{array}{c}154.98 * \\
* \\
\pm 2.78 \\
(-6.37)\end{array}$ & $\begin{array}{c}175.74 * * \\
\pm 3.27 \\
(+6.16)\end{array}$ & $\begin{array}{c}167.36^{@} \\
\pm 2.93 \\
(+1.09)\end{array}$ \\
\hline
\end{tabular}

All the values are \pm SD of six individual observations.

Values in parentheses denote per cent change over respective control.

** Values are significant at $\mathrm{P}<0.01$

@ Values are non significant

In the present study the glutathione peroxidase activity was decreased in both (young and old) nicotine treated rats (young by $-34.95 \%$; old by $-25.22 \%$ ) when compared to control rats. In red grape extract treated rats of both (young and old) an increased was observed when compared to the control rats (young by $7.74 \%$; old by $11.64 \%$ ). In the combination treatment (Nt+RGEt) slightly increased was observed when compared to control rats of both age groups (Table-4).

Table-4: Changes in Glutathione peroxidase (Gpx) activity in heart tissue of male albino rats of young ( 3 months) and old (18 months) age groups. Values are expressed in $\mu$ moles of thioether formed/ $\mathrm{mg}$ protein/min.

\begin{tabular}{|c|c|c|c|c|c|c|c|c|}
\hline \multirow{2}{*}{$\begin{array}{l}\text { Name } \\
\text { of the } \\
\text { tissue }\end{array}$} & \multicolumn{4}{|c|}{ Young } & \multicolumn{4}{c|}{ Old } \\
\cline { 2 - 9 } & Control & $\mathrm{Nt}$ & RGEt & Nt+RGEt & Control & $\mathrm{Nt}$ & RGEt & Nt+RGEt \\
\hline \multirow{3}{*}{ Heart } & 108.89 & $72.51^{* *}$ & $118.23^{* *}$ & $111.82^{@}$ & 92.76 & $68.67 * *$ & $103.20^{* *}$ & $95.15^{@}$ \\
& \pm 7.07 & \pm 4.58 & \pm 9.36 & \pm 7.07 & \pm 11.95 & \pm 9.55 & \pm 7.84 & \pm 8.83 \\
& $(-33.40)$ & $(+1.23)$ & $(+2.69)$ & & $(-25.97)$ & $(+11.25)$ & $(+2.57)$ \\
\hline
\end{tabular}

All the values are \pm SD of six individual observations.

Values in parentheses denote per cent change over respective control.

* Values are significant at $\mathrm{P}<0.05$

** Values are significant at $\mathrm{P}<0.01$

${ }^{\circledR}$ Values are non significant

\section{DISCUSSION:}

\section{Superoxide Dismutase (SOD)}

In the present study an decrease was absorbed in SOD activity in the heart tissue of both age groups, due to nicotine treatment. The present results in the current investigation are in consistence with the previous findings. Among the generated free radicals due to nicotine metabolism, superoxide anion is the first derived free radical from nicotine. Thus, increased generation of superoxide radicals caused oxidative stress and damages the heart cells. In fact SOD scavenges the superoxide radicals in the tissues. In addition, the over production of superoxide radicals due to nicotine intoxication implies 
the over utilization of SOD, this may indicate its low activity under nicotine induced oxidative stress condition. The decrease in SOD activity due to nicotine consumption may impairs the other antioxidant enzyme activities like catalase and glutathione peroxidase. Because the superoxide radicals that are produced in the heart tissue during nicotine metabolism are quickly scavenged to $\mathrm{H}_{2} \mathrm{O}_{2}$ by the enzyme superoxide dismutase. Under these circumstances, if SOD is not detoxifying the superoxide radical to hydrogen peroxide, there would be deficiency of substrate i.e., $\mathrm{H}_{2} \mathrm{O}_{2}$ for catalase and glutathione peroxidase enzyme activities. Thus, this kind of situation leads to impair the other antioxidant enzymes in the tissue metabolism.

The results of the present study showed a fall in SOD activity in the heart tissue, in the nicotine treated groups. SOD, dismutate $\mathrm{O}_{2}{ }^{-\bullet}$ and the same in turn is a potent inhibitor of CAT (Ashakumari and Vijayammal, 1996). The depletion in SOD activitywas may be due to dispose off the free radicals, produced due to nicotine toxicity. Beside this, on nicotine administration, $\mathrm{H}_{2} \mathrm{O}_{2}$ produced by dismutation of superoxide anion, may have been efficiently converted to $\mathrm{O}_{2}$ by CAT and the enzyme activities showed a marked reduction. The depletion of antioxidant enzyme activity was may be due to inactivation of the enzyme proteins by nicotine-induced ROS generation, depletion of the enzyme substrates, and/or down-regulation of transcription and translation processes.

In the present study the SOD activity was decreased due to nicotine treatment in the male albino rat in heart tissue. Similar studies have been reported by several authors. Kazim Husain et al., (2001) reported a significant depression of renal SOD activity was observed in nicotine treated rats. The observed decrease in renal SOD activity may be a consequence of decreased de novo synthesis of enzyme proteins or oxidative inactivation of enzyme protein.Chennaiah et al., (2006) reported due to nicotine treatment SOD activity was decrease in the muscle tissue. The depletion of SOD activity was may be due to dispose of the free radical, produced by the nicotine toxicity. Helen et al., (2000) reported the decreased SOD activity in brain tissue of rat due to nicotine toxicity. Sokkary et al., (2001) reported chronic administration of nicotine the SOD activity was decreased in the rat liver and lung. Chattopadhyay and Chattopadhyay (2008) reported due to nicotine treatment the SOD activity was decreased in ovary tissue. Similar changes in SOD activity was reported in various toxic conditions. Mahendran and Syamala Devi, (2001) reported decrease in SOD activity with $18 \%$ ethanol treatment in the hepatic tissue. Somani and Husain, (1997b) reported significant decrease in plasma and hepatic SOD activity with $20 \%$ of chronic ethanol treatment. When alcohol is metabolized in the liver by the MEOS pathway, a potentially dangerous by products such as, acetaldehyde and cytotoxic free radicals are generated (Temel et al., 2002, Licber, 2004). Evidences are exist that ethanol intake increases the oxidative stress in the liver (Chen and Cohen, 1995) and its toxicity is associated with elevated s generation of reactive oxygen species (Reinke et al., 1994). Among the generated free radicals due to ethanol metabolism, superoxide anion is the first derived free radical from ethanol. Thus, increased generation of superoxide radicals caused oxidative stress and damages the liver cells. Nordmann, (1994) showed that an acute ethanol load significantly enhanced superoxide generation in rat liver sub-mitochondrial particles.

In the present study heart SOD activity was increased with red grape extract treatment in both age groups of rats. This elevation was more pronounced in young age rats than old age rats. In vitro studies showed that grape juice has significant antioxidant activity and can inhibit oxidation of low density lipoprotein (LDL) (Castilla et al., 2006; O'Byrne et al., 2002). In addition to their antioxidant activity, polyphenols also possess many different biological properties. Normally phenolic compounds act by scavenging free radicals and quenching the lipid peroxidative side chain. It has been proposed that hydroxyl and hydroperoxy radicals initiate hydrogen abstraction from a free phenolic substrate to form phenoxy radicals that can rearrange to quinine methide radical intermediates which is excteted via bile (Rukkumani et al.,2005). Dani et al., (2007) reported the SOD activity was increased in rats when treated with organic grape juice. The activities of two major antioxidant enzymes, mitochondria 
SOD and cytosolic glutathione peroxidase (GSH-Px) were significantly higher in red grape extract treated animals than the control animals. The increased generation of free radicals i.e., superoxide anion radicals would have triggered the induction of SOD enzyme and hence SOD activity was elevated during red grape extract treatment. Among the various antioxidant enzymes SOD provides the first line of defense against superoxide radicals, elevated SOD activity may reduce the exposure of the hepatic tissue to superoxide radicals and perhaps hydroxyl radicals formed via the Haber-Weiss reaction (Halliwell and Gutteridge, 1989). In the present investigation increased heatr SOD activity during red grape extract treatment helps in preventing accumulation of superoxide anion radicals in the tissue of old age rats by converting them to $\mathrm{H}_{2} \mathrm{O}_{2}$ which is considered to be an adaptational change by red grape extract treatment to mitigate superoxide toxicity.

This study supported a long standing hypothesis that generation of oxygen derived free radicals and other reactive oxidants may be increased in aged heart tissue. These results were also agree with previous findings, which reported the decreased SOD activity with advancement of age (Rao et al., 1990). Vohra et al., (2001) reported the decrease in SOD activity in brain regions of 36 months old age guinea pigs. The reported decrease in SOD activity with age may further accelerated the aging process (Carilo et al., 3992). Miquel, (1980) and others postulated that mitochondrial decay is a significant factor in aging, caused, in jart, by the release of reactive oxygen species (ROS) as byproducts of mitochondrial electron transport. Several authors quoted that during aging, inner mitochondrial membrane being a major intracellular site for the generation of superoxide anion radicals, which are toxic to the body (Yan and Sohal, 1998; Bejma and Ji, 1999). Mitochondria are the targets of oxidant byproducts. The steady state and the percentage of oxygen converted to superoxide anion radical increased with age (Sohal et al., 1995; Perez et al., 1998; Sastre et al., 2000). SOD activity may also reduce in aging rats due to over utilization of SOD to counter the age induced free radicals in the heart tissue. Moderate red grape extract treatment produce a beneficial effect by decreasing the levels of oxidative stress markers in the mitochondria of heart and prevent the age associated decrease of antioxidant enzyme activities in the same organ. In the combination treatment $(\mathrm{Nt}+\mathrm{RGEt})$ observed upregulation of antioxidant enzyme activity, decrease in oxidative stress and increased activity of mitochondrial electron transfer enzymes, are logically related.

\section{CATALASE (CAT)}

In the present we found that the administration of nicotine was observed the decrease in CAT activity in the heart tissue. Similar studies have been reported by several authors.Chennaiah et al., (2006) reported due to nicotine treatment CAT activity was decreased in the muscle tissue. Helen $e t$ al., (2000) reported the decreased CAT activity in brain tissue of rat due to nicotine toxicity. Avati et al., (2005) reported chronic administration of nicotine the CAT activity was decreased in the rat kidney, liver and lung. The depletion of CAT activity was may be due to dispose of the free radical, produced by the nicotine toxicity. Similar changes in CAT activity was reported in various toxic conditions by varies authors. Bindu et al., (2002) reported the decrease in CAT activity with $4 \mathrm{~g} / \mathrm{kg}$ body weight alcohol treatment for a period of 50 days in Sprague Dawley albino rats. Recently Das and Vasudevan, (2005b) reported a significant decrease in CAT activity with $2 \mathrm{~g}$ by / $\mathrm{kg}$ body weight ethanol treatment for a period of 4 weeks in hepatic tissue of Wistar strain male albino rats. This ethanol induced decrease in CAT activity may be due to enzyme protein oxidation as a result of accumulation of $\mathrm{H}_{2} \mathrm{O}_{2}$ and other cytotoxic radicals (Somani et al., 1996). The decreased CAT activity with ethanol treatment indicates inefficient scavenging of hydrogen peroxide due to oxidative inactivation of enzyme. Husain and Somani, (1997a) reported a significant decrease in plasma CAT activity in alcohol treated rats. The lower levels of plasma CAT activity may be explained due to mobilization of iron, which can generate ROS and these species can release low molecular weight iron (Nordmann, et al., 1987). The two antioxidant enzymes namely SOD and CAT decreased significantly 
in the hepatic tissue of alcohol administered rats suggesting the increased damage to this tissue as a result of uncontrolled generation of partially reduced oxygen species (Mahendran and Shyamala Devi, 2001).

In the present study, in the both age groups of RGEt rats the CAT activity was increased. The increased catalase activity indicates its active involvement in the decomposition of hydrogen peroxide during red grape extract treatment. A change in the binding characteristics of enzyme to membrane or their release from peroxisomes has been proposed as a possible mechanism for the increased activity levels of CAT (Somani and Rayback, 1996). CAT and SOD are considered to be indispensable for the survival of the cell against deleterious effects of hydroperoxides. The combination of SOD and CAT provide an efficient mechanism for removal of free radicals from the cell (Husain et al., 1996; Bhaskar Reddy, 2002). In vitro studies showed that grape juice has significant antioxidant activity and can inhibit oxidation of low density lipoprotein (LDL) (Castilla et al., 2006; O'Byrne et al., 2002). In addition to their antioxidant activity, polyphenols also possess many different biological properties. Normally phenolic compounds act by scavenging free radicals and quenching the lipid peroxidative side chain. It has been proposed that hydroxyl and hydroperoxy radicals initiate hydrogen abstraction from a free phenolic substrate to form phenoxy radicals that can rearrange to quinine methide radical intermediates which is excreted via bile (Rukkumani et al., 2005). Similar studies have been reported by several authors. Dani et al., (2007) reported the CAT activity was increased in rats when treated with organic grape juice.

In the current investigation, catalase activity was decreased with advancement of age. The decreased CAT activity in old age animals may be due to increase in the oxidative stress with age. Demaree et al., (1999) reported the decreased aortic CAT activity in old age rats than in young rats. It was observed that decline in SOD activity with age may result in lower CAT activity in the kidney tissue. Rao et al., (1990) reported that the CAT activity was decreased in the tissues of liver, brain and kidney with aging. They also reported mRNA levels in the tissues of aged rats, which may result in the decreased activity of the enzyme in aged rats. Malsuo et al., (1992) also reported decreased CAT activity in the liver tissue between, 8, 14 and 32 months aged rats. The rates of mitochondrial superoxide and $\mathrm{H}_{2} \mathrm{O}_{2}$ generation were found to increase with age in mammals (Sohal el al., 1990; Jhansi Lakshmi, 1998). Age related increase in the hydrogen peroxide concentration in the tissues leads to decrease in CAT activity and cause oxidative stress in the tissues.

\section{GLUTATHIONE (GSH)}

In the present study we found that the administration of nicotine showing the decreased in GSH activity in the heart tissue. Similar studies have been reported by several authors. Chennaiah et al., (2006) reported due to nicotine treatment GSH activity was decrease in the muscle tissue. Sokkary et al., (2007) reported chronic administration of nicotine the GSH activity was decreased in the rat kidney, liver and lung. Saner et al., (2005) reported chronic administration of nicotine the GSH activity was decreased in the rat tissues. Nicotine is oxidized primarily into its metabolite cotinine in the liver (Sastry et al., 1995).

A similar change in GSH activity was reported in various toxic conditions by varies authors in varies tissues. Chronic ethanol consumption significantly depleted the GSH concentration in the hepatic tissue of different mammals like, rats (Mahendran and shyamala Devi, 2001; Kim et al., 2003) mice (Zhou et al., 2002) and man (Kannan et al., 2004; Das and Vasudevan, 2005a).One important antioxidant that is affected by alcohol is glutathione. Liver cells contain an abundance of glutathione, especially with in structures called mitochondria, where most of each cell's energy is generated. The key enzymes in mitochondria are certain cytochromes that are integral components of inner mitochondrial membrane. Glutathione is not synthesized in mitochondria; adequate concentrations of glutathione are maintained there by active transport form the cytoplasm through the mitochondrial 
membrane. Alcohol interferes with the transport of GSH through membranes, leading to its depletion from mitochondria. The resulting GSH deficiency may permit mitochondrial damage and cell death by means of unimpeded lipid peroxidation (Maher, 1997; Zhou et al., 2002). The decrease in GSH concentration in mitochondria would thus be highly responsible for ROS generation and the structural and functional damage in this organelle (Kannan et al., 2004). The decrease in GSH/ CSSG ratio in the hepatic tissue of ethanol fed rats and inhibition of GR activity are indicative of ethanol induced oxidative stress in the hepatic tissue. Depletion of hepatic GSH by chronic ethanol ingestion induced oxidative stress is well reputed.

In the present study the GSH activity was increased in both age groups supplemented with RGEt in the heart tissue of rat. Moreover, the percent elevation of GSH was more pronounced in old age group of rats compared to the young group of rats. Increased GSH content with RGEt may also due to the increase in the synthesis of precursors for GSH formation and increase the $\gamma$-GlutamylCystineglycine enzyme, which is very essential for the GSH. The synthesis and degradation of GSH is referred as the $\gamma$-Glutamyl cycle. This cycle small responsible for the enhanced GSH concentration in the heart tissue with red grape extracts treatment.

Age related an alteration in the levels of reduced glutathione seems to be very complicated. Decreased tissue concentrations of GSH have been reported in several diseased states and are associated with an increase risk to oxidative stress. GSH decrease may be due to increased oxidation of GSH or decreased in the synthesis of GSH and low decreased availability of precursors for GSH formation. Low glutathione reductase activity may also contribute to the lower levels of GSH in the tissues. Vohra et al., (2001) reported the decreased glutathione peroxides and glutathione,reductase activities in old age animals, indicate inadequate concentrations of GSH for their action in the tissues.

The decreased antioxidants with nicotine treatment were recovered with combination treatment in both ages. The combination treatment $(\mathrm{Nt}+\mathrm{RGEt})$ has the beneficial effect by enhancing the decreased antioxidants in the heart tissue. These results clearly indicate that the combination treatment for a period of 2 month would provide the favorable, condition to the cells by decrease the nicotine and improving their antioxidant aging caused oxidative stress capacity and / or decreased the nicotine and aging caused oxidative stress conditions in the heart tissue.

\section{GLUTATHIONE PEROX1DASE (GSH-Px)}

The present study reveals that the activity of glutathione peroxidase was decreased in nicotine treated rats in both age groups. Similar studies have been reported by several authors due to nicotine, hepatic GPx activity was decreased in mice (Vijayan and Helen, 2007), Wistar rats (Avti et al., 2006). The decreased GSH-Px activity in the current investigation may disturb the glutathione (GSH) homeostasis in the liver cell and ultimately it leads to the damage of hepatocytes. Several studies has been reported by varies authors in different toxic conditions. Kazeem et al., (2011) reported the GSHPx activity was decreased in the hepatic tissue. Recently Das and Vasudevan, (2005a) reported the decreased GSH-Px activity in the liver homogenate with a series of ethanol treatments like, $0.8 \mathrm{~g}, 1.2 \mathrm{~g}$, $1.6 \mathrm{~g}$ and $2.0 \mathrm{~g} / \mathrm{kg}$ body weight for a period of 4 weeks, our results also agreement with this. Decrease in GSH-Px activity may be due to either free radical dependant inactivation of enzyme or depletion of its co-substrate i.e., GSH and NADPH in the nicotine treatments. Similar studies, Santanu Kar Mahapatra et al., (2008) reported smoking decreases the Glutathione peroxidase in the serum of mans. $\mathrm{GP}_{\mathrm{X}}$ works nonspecifically to scavenge and decompose excess hydro peroxides including $\mathrm{H}_{2} \mathrm{O}_{2}$, which may prevalent under oxidative stress (Somani et al.,1996). In this study, decreased $\mathrm{GP}_{\mathrm{X}}$ activity seems to indicate the smoking induced oxidative stress. The decreased level of GSH and activity of GSHdependent enzymes i.e. $\mathrm{GP}_{\mathrm{X}}$, GR.

The results obtained from the present study reveals that red grape extract treatment enhanced the heart tissue glutathione peroxidase activity in both age groups of rats when compared to their 
respective controls. GSH-Px activity increased in heart tissue at a high level indicating an efficient elimination of organic peroxides (Husain and Somani, 1997a). By accepting an electron from the peroxide (or donating a hydrogen ion), GSH is oxidized to half of disulphide (GSSH). This reaction is catalyzed by Se-containing GSH-Px enzyme. The elevation of glutathione peroxidase activity due to red grape extract treatment (RGEt) suggests an increased capacity to handle hydroperoxides in the tissues. It appears that red grape extract treatment provide the required substrate for a high increase in the GSH-Px activity. Similar to the results obtained for SOD in this studies, the red grapr extract treatment induced upregulation of GSH-Px activity, appears that SOD and GSH-Px are actively involving in decomposing the oxygen derived free radicals in the heart tissue of old rats. The reason for higher GSH-Px activity in red grape extract treatment rats may be due to higher production of ROS and increased activity of SOD in the rats. However, the available reports suggest the fact that higher SOD activity may be responsible in part, for higher GSH-Px activity (Ray and Husain, 2002).

The specific activity of GSH-Px was remarkably decreased in old rats compared to the young rats. With the aging the GSH-Px activity was decreased in different animals and different tissues reported by varies authors. The age related decrease in heart tissue GSH-Px activity in the current study was supported by earlier reports also. Vohra et al., (2001) reported both cytosolic and mitochondrial GSH-Px activities were decreased in different brain' regions of 32 months old guinea pigs. There appears to be an inter relationship between the activity of SOD and GSH-Px. The deficiency of SOD has been shown to be associated with decrease in the activity of GSH-Px vice-versa (Michiels et al., 1994). Both Se-dependent and Se-independent GSH-Px were decreased in old rats compared with the young rats. The production of free radicals and other reactive oxygen species are believed to increase with age in most tissues (Lawler and Powers, 1998). These increased -free radicals especially hydrogen peroxide $\left(\mathrm{H}_{2} \mathrm{O}_{2}\right)$ may be responsible for the low activity of kidney glutathione peroxidase in older rats. The decreased SOD activity in old rats which was also reported in the present study may also be responsible for the lower GSH-Px activity, because of their interrelation in detoxifying the toxic radicals. This age related decrease in hepatic GSH-Px activity was augmented with red grape extract compared to control rats. Thus, red grape extract play a prominent role in preventing nicotine induced oxidative stress by promoting the GSH-Px activity in heart tissue in young and as well as old age rats.

In the present investigation the impact of red grape extract treatment on nicotine induced oxidative stress has been studied in the heart tissue with reference to aging on carbohydrate metabolic profiles, oxidative and antioxidant enzymes system by taking male albino rat as an experimental model.

Aging is the sum total of changes during an individual's life span which are common to all members of the species. If carbohydrates are infact the causative factors responsible for senescence, the maintenance of carbohydrate metabolism would minimize damage to physiological system and consequently the process of aging could be delayed. Red grape extract treatment enhances the ability to release energy by effective utilization of various metabolic fuels including stored ones, due to improved oxidative capacity. The survey of literature revealed that the reports on the effect of red grape extract, nicotine and aging is limited. Hence, the present investigation was programmed to elucidate the adaptive changes if any, induced by red grape extract treatment (RGEt), Nicotine treatment $(\mathrm{Nt})$ and both $\mathrm{Nt}+\mathrm{RGEt}$ on heart tissue with reference to aging.

\section{CONCLUSION:}

In the present study all the antioxidant enzymes (SOD, CAT, GSH and GSH-Px), the upregulation was found with the response of combination (Nt+RGEt) in both age groups of rats. The present study suggesting that RGEt may help to develop a resistance in the heart to cope with nicotine induced maintains the antioxidant system. 


\section{REFERENCES:}

1) Maier, T., Schieber, A., Kammerer, D.R and Carle, R.(2009). Residues of grape (Vitis vinifera L.) seed oil production as a valuable source of phenolic antioxidants. Food Chemistry 112: 551-559.

2) Lafka, T.I., Sinanoglou, V and Lazos, E.S. (2007). On the extraction and antioxidant activity of phenolic compounds from winery waste. Food Chemistry 104:1206-1214.

3) Pozo-Bayón, M.A.; Monagas, M.; Bartolome, B and Moreno-Arribas, M.V. (2012).Wine features related to safety and consumer health: An integrated perspective. Crit. Rev. Food Sci. Nutr., 52, 3154.

4) Arranz, S.; Chiva-Blanch, G.; Valderas-Martínez, P.; Medina-Remón, A. ;Lamuela-Raventós, R.M and Estruch, R. (2012). Wine, beer, alcohol and polyphenols on cardiovascular disease and cancer. Nutrients 4, 759-781.

5) Minussi, R.C.; Rossi, M.; Bologna, L.; Cordi, L.; Rotilio, D.; Pastore, G.M. and Durán, N.. (2003). Phenolic compounds and total antioxidant potential of commercial wines. Food Chem, 82, 409-416.

6) Pérez-Magariño, S.and González-Sanjosé M.L(2006). Polyphenols and colour variability of red wines made from grapes harvested at different ripeness grade. Food Chem., 96, 197-208.

7) Salas, E.; Fulcrand, H. and Meudec, E. (2003). Cheynier, V. Reactions of anthocyanins and tannins in model solutions. J. Agric. Food Chem., 51, 7951-7961.

8) Grana, R; Benowitz, Nand Glantz, SA (13 May 2014). "E-cigarettes: a scientific review.". Circulation. 129 (19): 1972-86. doi:10.1161/circulationaha.114.007667. PMC 4018182. PMID 24821826.

9) Holbrook and Bradley D. (2016). "The effects of nicotine on human fetal development". Birth Defects Research Part C: Embryo Today: Reviews. 108 (2): 181-92. doi:10.1002/bdrc.21128. ISSN 1542-975X. PMID 27297020.

10) Mayer B (January 2014). "How much nicotine kills a human? Tracing back the generally accepted lethal dose to dubious self-experiments in the nineteenth century". Archives of Toxicology. 88 (1): $5-7$.

11) Caponnetto, Pasquale; Campagna, Davide; Papale, Gabriella; Russo, Cristina; Polosa and Riccardo (2012)."The emerging phenomenon of electronic cigarettes". Expert Review of Respiratory Medicine. 6 (1): 63-74. doi:10.1586/ers.11.92. ISSN 1747-6348. PMID 22283580.

12) Kozlowski LT, Mehta NY, Sweeney CT, Schwartz SS, Vogler GP, Jarvis MJ and West RJ(1998). Filter ventilation and nicotine content of tobacco in cigarettes from Canada, the United Kingdom, and the United States. Tob Control 7(4):369-375.

13) Benowitz NL, and Jacob P 3rd (1984). Daily intake of nicotine during cigarette smoking. Clin Pharmacol Ther 35(4):499-504.

14) Armstrong.DW, Wang. X,and Ercal.N,(1998). Enantiomeric composition of nicotine in smokeless tobacco, medicinal prodicts and commercial reagents Chirality:10:587-591.

15) Jacob P, 3rd, Yu L, Shulgin AT, and Benowitz NL (1999). Minor tobacco alkaloids as biomarkers for tobacco use: comparison of users of cigarettes, smokeless tobacco, cigars, and pipes. Am J Public Health 89(5):731-736.

16) Leete E(1983). Biosynthesis and metabolism of the tobacco alkaloids. In: Pelletier SW (ed) Alkaloids: chemical and biological perspectives. Wiley, New York, pp 85-152.

17) Tyroller S, Zwickenpflug W, and Richter E (2002). New sources of dietary myosmine uptake from cereals, fruits, vegetables, and milk. J Agric Food Chem 50(17):4909-4915.

18) Siegmund B, Leitner E, and Pfannhauser W (1999). Determination of the nicotine content of various edible nightshades (Solanaceae) and their products and estimation of the associated dietary nicotine intake. J Agric Food Chem 47(8):3113-3120. 
19) Patel, P.J. (1981). Aging and antimicrobial immunity. Impaired production of mediator T cells as a basis for the decreased resistance of senescent mice to listeriosis, J.Exp.Med.,154: 821-831.Shock, N.W. (1979). In "Health Book" (Ed. K. George). North Holland Publishing Company, 115-150.

20) Harman, D. (1992). Free radical theory of aging. Mutat. Res., 275: 257-266.

21) Masoro, E.J. (1993). Concepts and hypothesis of basic aging aprocesses by CRC press IC in Free radicals in aging by Byung pal yu.

22) Jang, I., Chae, K., and Cho, J. (2001). Effects of age and strain on small intestinal and hepatic antioxidant defense enzymes in Wister and Fisher 344 rats. Ageing.Dev., 122 (6): 561-570.

23) Misra,H.P. and Fridovich, I.(1972). The role of superoxide anion in the utoxidation of epinephrine and a simple assay for superoxide dismutase. J Biol Chem : 247: 3170-3175.

24) Aebi, H., (1984). Methods Enzymol., 105: 125-126.

25) Theodorus,P.M.,Akerboom and Helmut Sies.(1981).Assay of Glutathione, Glutathione disulfide and glutathione mixed disulfide in biological samples. Methods in Enzymol.,77: 373-382.

26) Flohe, L., Gunzler, W.A.(1984).Methods Enzymol .105:115-121.

27) Pigeolot, E., Corbisier, P., Lambert, D., Michiels, C., Raes, M., Zachary, M.O., Ramacle, J., (1990). Mech. Age. 51, 283-297.

28) Ohkawa, H., Ohishi, N, Yagi, K., (1979). Anal Biochem ; 95, 351-358

29) Jang, I.,Chae,K., and Cho,J.(2001). Effects of age and strain on small intestinal and hepatic antioxidant defense enzymes in Wister and Fisher 344 rats. Ageing.Dev., 122 (6): 561-570.

30) Ashakumary, L.and Vijayammal, P. L. (1996). Additive effect of alcohol and nicotine on lipid peroxidation and antioxidant defence mechanism in rats. Appl J Toxicol., 16: 305-8.

31) Kazim Husain, Benjamin, R., Ccott, Sathya K., Reddy, Satu ,M.., and Somani. (2001). Chronic ethanol and nicotine interaction on rat tissue antioxidant defense system, Alcohol., 25:89-97.

32) Chennaiah, K. (2006). Effect of nicotine on superoxide dismutage, xanthione oxidase and catalase activities in the skeletal muscle fibres of albino rat.An international research journal of Bulletin of Pure and applied Sciences., 25 (1): 49-54.

33) Helen, A., K. Krishnakumar, P.L. Vijayammal and K.T. Augusti. (2000). Antioxidant effect of onion oil (Allium cepa. Linn) on the damages induced by nicotine in rats as compared to alphatocopherol. Toxicol. Lett., 116:61-68.

34) El-Sokkary,G.H., Cuzzocrea,S. and Reiter,R.J.,(2007). Effect of chronic nicotine administration on the rat lung and liver: beneficial role of melatonin. Toxicology.,239(1-2):60-7.

35) Chattopadhyay, K. and Chattopadhyay, B.D. (2008). Effect of nicotine on lipid profile, peroxidation $\&$ antioxidant enzymes in female rats with restricted dietary protein, Indian J.Med Res ,127: 571576.

36) Mahendran, P. and Shyamala Devi, C.S. (2001). The modulating effect of Garcinia Cambogia extract on ethanol induced peroxidative damage in rats. Ind. Pharmacoi., 33:87-91.

37) Somani, S.M. and Husain, K. (1997b). Interaction of exercise training and chronic ethanol ingestion on hepatic and plasma antioxidant system in rat. J. Appl. Toxicol., 17(3): 189-194.

38) Temel, I., Bay, E.O., Cigli, A. and Akyol, O. (2002). Erythrocyte catalase activities in alcohol consumption, medications and some diseases. Inonu. Univer. Faku. Derg., 9(1): 11-14.

39) Lieber, C.S. (2004). Alcoholic fatty liver: its pathogenesis and mechanism of progression to inflammation and fibrosis. Alcohol., 34: 9-19.

40) Nordmann, R. (1994). Alcohol and antioxidant systems. Alco. Alcohol.29(5):513-522.

41) Castilla, P., Echarri, R., Davalos, A., Cerrato, F., Ortega, H., Teruel, J.L., Lucas, M.F., GomezCoronado, D., Ortuno, J., and Lasuncion, M.A., (2006). Concentrated red grape juice exerts antioxidant, hypolipidemic, and antiinflammatory effects in both hemodialysis patients and healthy subjects. Am. J. Clin. Nutr., 84:252-262. 
42) O'Byrne, D.J., Devaraj, S., Grundy, S.M., Jialal, I., (2002). Comparison of the antioxidant effects of Concord grape juice flavonoids alphatocopherol on markers of oxidative stress in healthy adults. Am. J. Clin. Nutr., 76:1367-1374.

43) Rukkumani R, Aruna K, Varma PS, Rajasekaran KN, Menon VP.( 2004). Comparative effects of curcumin and an analog of curcumin on alcohol and PUFA induced oxidative stress. $J$ Pharm Pharm Sci; 7:274-83.

44) Dani, C., Oliboni, L.S., Pasquali, M.A., Oliveira, M.R., Umezu, F.M., Salvador, M., Moreira, J.C., and Henriques, J.A., (2008). Intake of purple grape juice as a hepatoprotective agent in Wistar rats. J Med Food. 11(1):127-32.

45) Chen, L.H., Xi, S. and Cohen, D.A. (1995). Liver antioxidant defense in mice fed ethanol and the AIN-76A diet. Alcohol., 12: 453-457.

46) Reinke, L.A., Moore, D.R., Hague, C.M. and McCoy, P.B. (1994). Metabolisms of ethanol to Ihdroxyethyle radicals in rat liver microsomes- comparative studies with three spin trapping agents. Free. Rad. Res., 21: 213-222.

47) Halliwell. B, and Gutteridge. J.M.C. (1989). Free radicals in biology and medicine. Ed. 2 Oxford, Clarendon Press., 136-158.

48) Rao, G, Xia E., Richardson, A. and Nadakavukaren, M.J. (1990). Effect of dietary restriction on the age dependent change in the expression of antioxidant enzymes in rat liver. J. Nutr., 120: 602-607.

49) Vohra, B.P.S., Sharma, S.P. and Kansal, V.K. (2001). Age dependent variations in mitochondrial and cytosolic antioxidant enzymes and lipid peroxidation in different regions of central nervous system of guinea pigs. Ind. J. Biochem. Biophy., 38:321-326.

50) Yan, L.J. and Sohal, R.S. (1998). Mitochondrial adenine nucleotide translocase is modified oxidatively during aging. Biochem., 95: 12896-12901.

51) Carillo, M.C., Canai, S., Sato, Y. and Kitani, K. (1992). Age related changes in antioxidant enzyme activities are region and organ as well as sex, selective in the rai.Mech. Age. Dev., 65:187-198.

52) Miquel,J.,Economous,A.C.,Fleming,J.,and Johnson,J.E.(1980).Exp.Gerontol.,15:575-591.

53) Bejma, J. and Ji, L.L. (1999). Aging and acute exercise enhance free radical generation in rat skeletal muscle. J. Appl. Physiol., 87: 465-470.

54) Sohal, R.S. and Orr, W.C. (1995). Is oxidative stress a casual factor in aging? In: Esser, K., Martin, G. M. eds., Molecular aspects of aging. Chichester: John Wiley and sons., 109-127.

55) Perez-Campo, R., Lopez-Torres, M., Cadenas, S., Rojas, C. and Barja, G. (1998). Comp. Physiol., 168: $149-158$.

56) Sastre, J., Pallardo, F. V. and Vina. J. (2000). IUBMB.. Life. 49: 427-435.

57) Avti PK, Kumar S, Pathak CM, Vaiphei K, Khanduja KL. (2006). Smokeless tobacco impairs the antioxidant defense in liver, lung, and kidney of rats. Toxicol Sci.,89(2):547-53.

58) Bindu, M. P.,Sreekant, K.S., Annamali, P.T. and Augusti, K.T. (2002). Effect of S-allile cysteine sulophoxide on lipid metabolism and free radical scavenges in alcohol fed rats. Curr. Sci., 82(6): 628-631.

59) Das, S.K. and Vasudevan, D.M. (2005b). Effect of ethanol on liver antioxidant defense system: A dose dependent study. Indi. J. Clini. Biochem., 20(1): 80-84.

60) Husain, K. and Somani, S.M. (1997a). Interaction of exercise and ethanol on hepatic and plasma antioxidant system in rat. Pathophysiol., 4: 69-74.

61) Somani, S.M. and Husain, K. (1996). Exercise training alters kinetics of antioxidant enzymes in rat tissues. Biochem. Mole. Biolo. Inter., 38(3): 587-595.

62) Nordmann. R., Ribiere. C. and Rouach. H. (1987). Involvement of iron and iron-catalyzed free radcial production in ethanol metabolism and toxicity. Enzyme., 37: 57-69.

63) Mahendran, P. and Shyamala Devi, C.S. (2001). The modulating effect of Garcinia Cambogia extract on ethanol induced peroxidative damage in rats. Ind. Pharmacoi., 33:87-91. 
64) Somani, S. M. and Ryback, L.P. (1996). Comparative effects of exercise training on transcription of antioxidant enzyme and the activity in old rat heart. Ind. J. Physiol. Pharmacol. 40 (3): 205-212.

65) Husain, K., Dube, S.N., Sugenolran, K., Singh, R., Das Gupta, S. and Somani, S.M. (1996). Effect of topically applied sulphur mustard on antioxidant enzymes in blood cells and body tissues of rat. $J$. Appl. Toxicol., 16: 245-248.

66) Bhaskar Reddy, T. (2002). Exercise induced changes in the antioxidant enzyme status and associated metabolic profiles of young and old rats. Ph.D. Thesis, S. V. University, Tirupati, India.

67) Castilla, P., Echarri, R., Davalos, A., Cerrato, F., Ortega, H., Teruel, J.L., Lucas, M.F., GomezCoronado, D., Ortuno, J.,and Lasuncion, M.A., (2006). Concentrated red grape juice exerts antioxidant, hypolipidemic, and antiinflammatory effects in both hemodialysis patients and healthy subjects. Am. J. Clin. Nutr., 84:252-262.

68) O'Byrne, D.J., Devaraj, S., Grundy, S.M., Jialal, I., (2002). Comparison of the antioxidant effects of Concord grape juice flavonoids alphatocopherol on markers of oxidative stress in healthy adults. Am. J. Clin. Nutr., 76:1367-1374.

69) Rukkumani R, Aruna K, Varma PS, Rajasekaran KN, Menon VP.( 2004). Comparative effects of curcumin and an analog of curcumin on alcohol and PUFA induced oxidative stress. $J$ Pharm Pharm Sci; 7:274-83.

70) Dani, C., Oliboni, L.S., Pasquali, M.A., Oliveira, M.R., Umezu, F.M., Salvador, M., Moreira, J.C., and Henriques, J.A., (2008). Intake of purple grape juice as a hepatoprotective agent in Wistar rats. J Med Food. 11(1):127-32.

71) Demaree, S.R., Lawler, J.M. Lenehan, J. and Delp, M.D. (1999). Aging alters aortic antioxidant enzyme activities in Fischer-344 rats. Acta. Phyiol. Scand., 166: 203-208.

72) Rao, G, Xia E., Richardson, A. and Nadakavukaren, M.J. (1990). Effect of dietary restriction on the age dependent change in the expression of antioxidant enzymes in rat liver. J. Nutr. 120: 602-607.

73) Matlsuo, M., Gomi, F. and Dooley. M.M. (1992). Age related alterations in antioxidant capacity and lipid peroxidation in brain, liver and lung homogenates of normal and vitamin $\mathrm{E}$ deficient rats. Mcch. Ageing Dev. 64:

74) Sohal, R., Arnold, L. and Sohal, B. (1990). Age related changes in antioxidant enzymes and prooxidant generation in tissues of the rat with special reference to parameters in two insect species. Free Rad. Biol. Med., 10: 495-500.

75) Jhansi Lakshmi, C. (1998). Metabolic modulation of antioxidant defense in aged rats by endurance exercise training. Ph.D. Thesis, S. V. University, Tirupati, India.

76) El-Sokkary,G.H., Cuzzocrea,S. and Reiter,R.J.,(2007). Effect of chronic nicotine administration on the rat lung and liver: beneficial role of melatonin. Toxicology., 239(1-2):60-7.

77) Sener, G., Sehirli, A.O., Ipçi, Y., Cetinel, S., Cikler, E., Gedik, N.,( 2005). Chronic nicotine toxicity is prevented by aqueous garlic extract. ant Foods Hum Nutr., 60(2):77-86.

78) Sastry, B.V., Chance, M.B., Singh, G., Horn, J.L., Janson, V.E. (1995). Distribution and retention of nicotine and its metabolite, cotinine, in the rat as a function of time. Pharmacology 50:128-136.

79) Das, S.K. and Vasudevan, D.M. (2005a). Biochemical diagnosis of alcoholism. Ind J. Clin. Biochem., 20(1): 35-42.

80) Mahendran, P. and Shyamala Devi, C.S. (2001). The modulating effect of Garcinia Cambogia extract on ethanol induced peroxidative damage in rats. Ind. Pharmacoi., 33:87-91.

81) Kim, Y.C. Kim, Y.S. and Sohn, Y.R. (2003). Effect of age increase on metabolism and toxicity of ethanol in female rats. Life Sci., 74: 509-519.

82) Zhou, Z., Sun, X. and Kang, Y.J. (2002). Metallothionein protection against alcoholic liver injury through inhibition of oxidative stress. Exp. Biol. Med., 227(3): 214-222.

83) Kannan, M., Wang, L. and Kang, Y.J. (2004). Myocardial oxidative stress and toxicity induced by acute ethanol exposure in mice. Exp. Biol. Med. 229: 553-559. 
84) Das, S.K. and Vasudevan, D.M. (2005a). Biochemical diagnosis of alcoholism. Ind J. Clin. Biochem,. 20(1): 35-42.

85) Maher, J.1. (1997). Exploring alcohol's effects on liver functions. Alco. Health Res. World. 21(1): 512.

86) Vijayan, V.,and Helen, A. (2007). Protective activity of Bacopa monniera Linn. on nicotine-induced toxicity in mice. Phytother Res. 21(4):378-81.

87) Kazeem, M.I., Bankole, H.A. and Fatai, A.A. (2011).Protective effect of ginger in normal and carbon-tetrachloride induced hepatotoxic rats.Annals of Biological Research., 2 (1): 1-8.

88) Somani, S.M. and Husain, K. (1996). Exercise training alters kinetics of antioxidant enzymes in rat tissues. Biochem. Mole. Biolo. Inter. 38(3): 587-595.

89) Santanukar mahapatra et al.,(2008).Smoking induced oxidative stress in serum and neutrophil of the University students. Al Ameen J Med Sci.1(1):20-31.

90) Vohra, B. P. S., Sharma, S. P. and Kansal, V. K. (2001). Age dependent variations in mitochondrial and cytosolic antioxidant enzymes and lipid peroxidation in different regions of central nervous system of guinea pigs. Ind. J. Biochem. Biophy., 38:321-326.

91) Michiels, C., Raes, M., Toussaint, O. and Remacle, J. (1994). Free. Rad. Biol. Med., 17: 235-248.

92) Lawler, J.M. and Powers, S.K. (1998). Oxidative stress, antioxidant capacity and the contracting diaphragm. Can. J. Appl. Physiol., 23-1: 23-55. 